\title{
Herpetological Journal \\ https://doi.org/10.33256/31.3.162169 \\ New evidence for distinctiveness of the island-endemic Príncipe giant tree frog (Arthroleptidae: Leptopelis palmatus)
}

\author{
Kyle E. Jaynes ${ }^{1,2,3,4}$, Edward A. Myers ${ }^{2}$, Robert C. Drewes ${ }^{5}$ \& Rayna C. Bell ${ }^{2,5}$ \\ ${ }^{1}$ Department of Biology, Adrian College, Michigan, USA \\ 2 Department of Vertebrate Zoology, National Museum of Natural History, Smithsonian Institution, Washington, D.C., USA \\ ${ }^{3}$ Department of Integrative Biology, Michigan State University, Michigan, USA \\ ${ }^{4}$ Ecology, Evolution, and Behavior Program, Michigan State University, Michigan, USA \\ ${ }^{5}$ Herpetology Department, California Academy of Sciences, California, USA
}

The Príncipe giant tree frog Leptopelis palmatus is endemic to the small oceanic island of Príncipe in the Gulf of Guinea. For several decades, this charismatic but poorly known species was confused with another large tree frog species from continental Africa, L. rufus. Phylogenetic relationships within the African genus Leptopelis are poorly understood and consequently the evolutionary history of $L$. palmatus and its affinity to $L$. rufus remain unclear. In this study, we combined mitochondrial DNA (mtDNA), morphological, and acoustic data for L. palmatus and L. rufus to assess different axes of divergence between the species. Our mtDNA gene tree for the genus Leptopelis indicated that L. palmatus is not closely related to $L$. rufus or other large species of Leptopelis. Additionally, we found low mtDNA diversity in L. palmatus across its range on Príncipe. We found significant morphological differences between females of $L$. rufus and $L$. palmatus, but not between males. We characterised the advertisement call of $L$. palmatus for the first time, which is markedly distinct from $L$. rufus. Finally, we summarised our observations of $L$. palmatus habitats and additional notes on phenotypic variation and behaviour. Our study reinforces the distinctiveness of $L$. palmatus and provides information important for the conservation of this endangered species.

\begin{abstract}
A rã gigante de Príncipe, Leptopelis palmatus, é endêmica da pequena ilha oceânica de Príncipe no Golfo da Guiné. Por várias décadas, esta espécie carismática mas pouco conhecida foi confundida com outra espécie grande de rã da África continental, L. rufus. As relações filogenéticas dentro do gênero africano Leptopelis são mal compreendidas e, conseqüentemente, a história evolutiva de L. palmatus e sua afinidade com L. rufus permanecem obscuras. Neste estudo, combinamos dados de DNA mitocondrial (mtDNA), morfológicos e acústicos de L. palmatus e $L$. rufus para avaliar diferentes eixos de divergência entre as espécies. Nossa árvore de genes de mtDNA para o gênero Leptopelis indicou que L. palmatus não está proximamente relacionada a $L$. rufus ou outras espécies grandes de Leptopelis, e encontramos baixa diversidade de mtDNA em L. palmatus em toda a sua distribuição em Príncipe. Encontramos diferenças morfológicas significativas entre as fêmeas de $L$. rufus e L. palmatus, mas não entre os machos. Caracterizamos o canto reprodutor de L. palmatus pela primeira vez, que é marcadamente distinto do de $L$. rufus. Finalmente, resumimos nossas observações dos habitats de $L$. palmatus e notas adicionais sobre variação fenotípica e comportamento. Nosso estudo fornece informações importantes para a conservação dessa espécie ameaçada de extinção
\end{abstract}

Keywords: bioacoustic, morphology, endemic, mitochondrial DNA, island, São Tomé and Príncipe

\section{INTRODUCTION}

$T$ he Príncipe giant tree frog Leptopelis palmatus (Peters, 1868) is endemic to the small $\left(142 \mathrm{~km}^{2}\right)$ oceanic island of Príncipe in the Gulf of Guinea. For several decades, this charismatic but poorly known species was confused with another large tree frog species from continental Africa, L. rufus Reichenow 1874 (Anderson, 1909; Parker, 1936; de Witte, 1941; Perret, 1962). Phylogenetic relationships within the African genus Leptopelis are poorly understood and consequently the evolutionary history of $L$. palmatus and its affinity to $L$. rufus remain unclear. Previous authors have hypothesised that $L$. palmatus is closely related to $L$. rufus and other large-bodied species in West and Central Africa (L. macrotis, L. millsoni) based on a combination of mtDNA and morphological data (e.g., Idris, 2004). A more recent study estimating diversification across Afrobratrachia, which is composed of the families Arthroleptidae, Brevicipitidae, Hemisotidae, and Hyperoliidae, does not support this relationship (Portik et al., 2019); however, relationships among Leptopelis were not the primary focus of that study and the molecular data matrix was a combination of mtDNA and very sparse nuDNA loci. Here we include more comprehensive sampling of Leptopelis diversity (55\% of currently recognised species) and use a complete mtDNA data matrix with the sole aim of identifying the

Correspondence: Kyle E. Jaynes (jaynesky@msu.edu) 
closest continental relatives of the island endemic. We also generate mtDNA sequence data from $L$. palmatus collected across its elevational and geographic range on Príncipe to assess genetic diversity and phylogeographic structure within the species.

Throughout nearly a century of taxonomic confusion between L. palmatus and L. rufus, L. palmatus was reported from several countries including Cameroon, Equatorial Guinea (including Bioko Island), Gabon, and Nigeria (Boulenger, 1882; Mocquard, 1902; Boulenger, 1906; Nieden, 1910; Ahl, 1931; Schiøtz, 1963; Mertens, 1965). After comparing a large series of male and female L. rufus with the sole female holotype of $L$. palmatus available for study, Perret resurrected $L$. rufus and clarified that $L$. palmatus was an insular species (Perret, 1973). Perret also remarked that $L$. rufus and $L$. palmatus differed in tympanum size and several additional morphological features, concluding that despite decades of taxonomic confusion the two species may not even be closely related (Perret, 1973). Loumont later collected a series of eight $L$. palmatus females, confirmed the results of Perret's morphological study and reported a snout-vent length of up to $110 \mathrm{~mm}$, which remains the largest size record for the entire genus (Loumont, 1992; Channing \& Rödel, 2019). Male specimens of $L$. palmatus were finally collected and formally described following an expedition to Príncipe in 2002 (Drewes \& Stoelting, 2004). We have since collected additional male and female specimens of L. palmatus, providing the opportunity to compare large series of both sexes of $L$. palmatus and $L$. rufus to assess phenotypic variation within and between the species.

Very little is known about the natural history of Leptopelis palmatus, an endangered island endemic (IUCN SSC Amphibian Specialist Group, 2020). Although males lack vocal sacs (Drewes \& Stoelting, 2004), they do produce advertisement calls and here we report the first recording and analysis of their call, which we compare to that of $L$. rufus. We also summarise our observations of L. palmatus habitats and additional notes on phenotypic variation and behaviour. In summary, our study combines mitochondrial DNA (mtDNA), morphological, and acoustic data for $L$. palmatus and $L$. rufus to assess different axes of divergence between the species. We couple our findings of distinctness of $L$. palmatus with additional notes on phenotypic variation and behaviour to provide important information for the conservation of this endangered species.

\section{METHODS}

\section{Field sampling}

We conducted six herpetological expeditions to Príncipe Island between 2001 and 2016, during which we searched for Leptopelis palmatus. Tissue samples (including liver or muscle) were preserved in $95 \%$ ethanol or RNAlater and voucher specimens were fixed in formalin. The specimens were deposited at the California Academy of Sciences (CAS) and the U.S. National Museum of Natural History (USNM).

\section{Phylogenetic and Population Genetic Analyses}

We obtained 165 mtDNA sequences for 30 species in the genus Leptopelis (55\% of the currently recognised species) and two confamilial outgroups (Arthroleptis and Cardioglossa; Portik \& Blackburn, 2015) from GenBank, only selecting sequences with associated voucher specimens (Table S1). We aligned the sequences with MAFFT using the automatic algorithm selection option (--auto) (Katoh et al., 2002; Katoh \& Standley, 2013) and selected the HKY + I + G substitution model based on BIC in jModelTest (Darriba et al., 2012). To perform Bayesian phylogenetic analyses, we used BEAST v1.8 (Drummond et al., 2012) with a birth-death tree prior (Stadler, 2009), and a lognormal relaxed molecular clock. Two independent analyses were run for 10 million generations each with sampling every 1,000 generations, producing a total of 20,000 trees. We assessed convergence and the effective sample size of parameter estimates using Tracer v1.7 (Rambaut et al., 2018) and repeated simulations without sequence data to test the influence of priors on posterior distributions. We discarded a burn-in of 10 $\%$ prior to generating a maximum clade credibility tree from the remaining 18,000 trees.

To assess mtDNA structure across the entire known geographic and elevational range of $L$. palmatus, we extracted DNA from 35 tissue samples using a DNeasy Blood \& Tissue kit (Qiagen Inc., Valencia, CA, USA), and polymerase chain reaction (PCR)-amplified and cycle sequenced a portion of the $16 \mathrm{~s}$ mitochondrial gene using the primers 16SA and 16SB (Palumbi et al., 1991). Each reaction contained the following components: $1 \mu \mathrm{L}$ of template DNA, $6.05 \mu \mathrm{L} \mathrm{H}$ O, $1.75 \mu \mathrm{L}$ 10X Buffer, $0.3 \mu \mathrm{L}$ of each primer, $0.25 \mu \mathrm{L}$ dNTPs, $0.1 \mu \mathrm{L}$ of Bovine serum albumin (BSA), $0.1 \mu \mathrm{L}$ of $\mathrm{MgCl}$, and $5 \mu \mathrm{L}$ of goTAQ DNA Polymerase (Promega, Madison, WI, USA). We used a thermocycler protocol for amplification beginning with denaturation for $1 \mathrm{~min} 30$ seconds at $94{ }^{\circ} \mathrm{C}$, followed by 33 cycles, which consisted of 45 s denaturation at 94 ${ }^{\circ} \mathrm{C}, 45 \mathrm{~s}$ annealing at $55^{\circ} \mathrm{C}$, and $1 \mathrm{~min} 30$ s extension at $72{ }^{\circ} \mathrm{C}$, followed by the final extension occurring at 72 ${ }^{\circ} \mathrm{C}$ for $5 \mathrm{~min}$. We purified PCR products using ExOSAPIT (USB Corp., Cleveland, OH, USA) and carried out sequencing using a BigDye Terminator Cycle Sequencing Kit v3.1 (Applied Biosystems, Foster City, CA, USA) on an $A B I$ automated 3730xl Genetic Analyzer (Applied Biosystems). All sequences were edited using Geneious v.R8.0.04 (Biomatters Ltd.) and are available on GenBank (see Supplementary Materials). Due to the limited genetic diversity in our dataset, we estimated a mtDNA haplotype network using the TCS algorithm (Clement et al., 2000) implemented in PopArt (Leigh \& Bryant, 2015).

\section{Morphological data collection and analysis}

To assess the maximum reported female body size of L. palmatus relative to other species included in the phylogeny of the genus we obtained measurements from the literature (Table S1) and plotted them alongside the phylogeny. To compare variation in diagnostic traits between L. rufus and L. palmatus (Perret, 1973; Schiøtz, 1999), we took morphological measurements of adult 
A

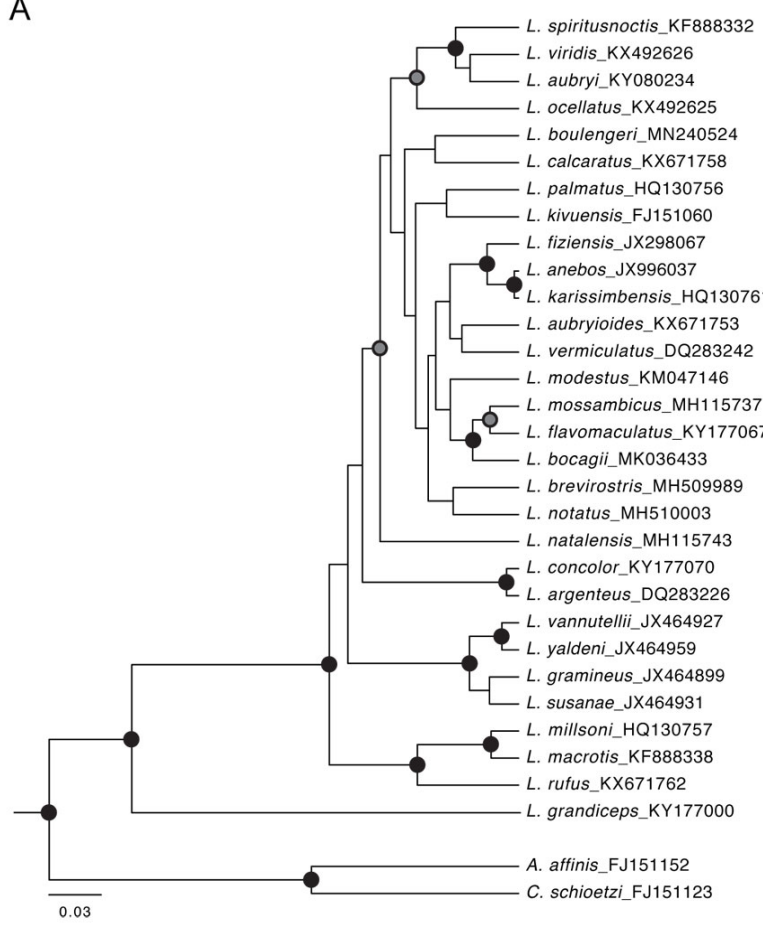

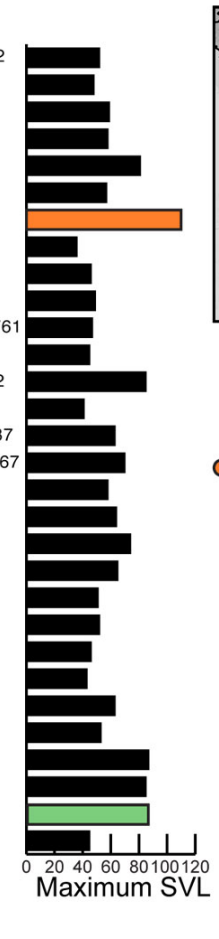

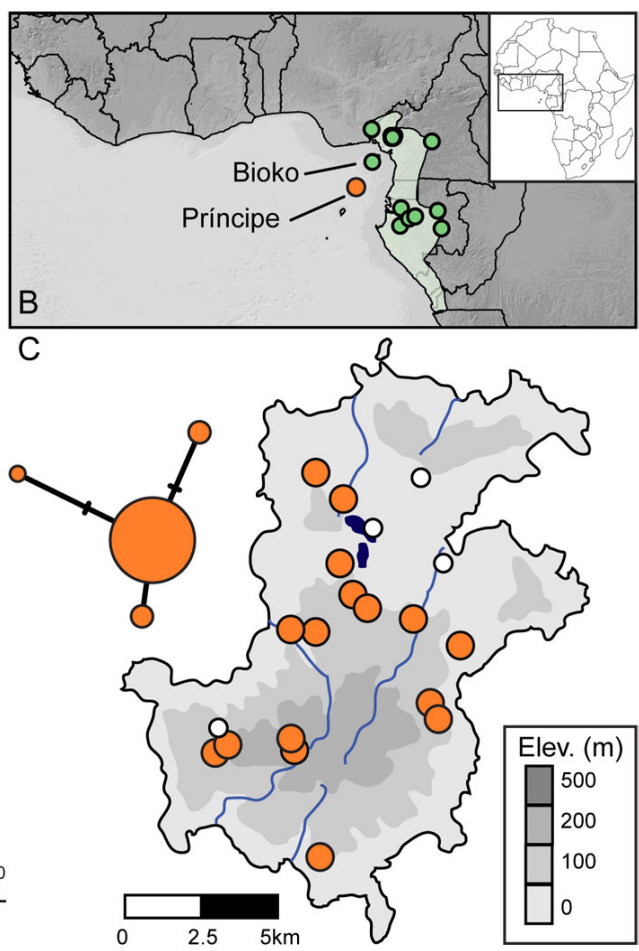

Figure 1. (a) $16 \mathrm{~S}$ mtDNA gene tree of 30 currently recognised species in the genus Leptopelis with maximum female (the larger sex) snout-vent length (SVL) in millimetres. Black circles on nodes indicate $>0.95$ posterior probability, grey circles indicate $>0.85$ posterior probability. All other nodes are poorly supported. (b) Geographic sampling of $L$. rufus and $L$. palmatus examined in this study. (c) Sampling map and mtDNA haplotype network for L. palmatus on Príncipe Island. Open circles indicate additional localities with vouchered $L$. palmatus specimens that are currently housed in the Museu Nacional de História Natural e da Ciência, Universidade de Lisboa, Portugal (Ceríaco, 2016; Ceríaco \& Marques, 2018).

frogs to the nearest $0.1 \mathrm{~mm}$ using Mitutoyo Absolute Digimatic Callipers. The following measurements were taken by KEJ and RCB: snout-vent length (SVL); eye diameter, measured as the ocular aperture (EYE); maximum horizontal diameter of left tympanum, measured to outer margin of tympanic rim (TMP); and maximum diameter of disc toepad, measured from the fourth digit of the left hindfoot (DSC). The ratios TMP:EYE and DSC:TMP have been proposed as useful diagnostic comparisons, but without accounting for potential sexual variation (Schiøtz, 1999). Sex was determined by a) snout-vent length, b) the presence (or absence) of pectoral glands in preserved specimens, c) the presence of eggs, or d) field notes indicating calling behaviour. A total of 109 adult specimens were measured (39 L. palmatus and 70 L. rufus). Male and female measurements were analysed separately to account for sexual size dimorphism. We omitted 10 samples that could not be identified to sex, resulting in a dataset of 58 male (19 L. palmatus and 39 L. rufus) and 41 female specimens (17 L. palmatus and 24 L. rufus). To account for allometry across individuals, we corrected TMP measurements (Thorpe, 1975; Thorpe, 1983a; Thorpe, 1983b; Turan, 1999) using the allometric equation: $X a d j=X-\beta(S V L-S V L m e a n)$. In this equation, Xadj is the adjusted value of the morphometric variable measurement, $X$ is the original value taken from the dial callipers, $\beta$ is the coefficient of the linear regression of $X$ against SVL in the dataset, SVL is the snout-vent length of the individual, and SVLmean is the overall mean snoutvent length in the dataset. To quantify divergence in
SVL, TMP, TMP:EYE, and DSC:TMP, we fit an ANOVA for each set of traits with measurements grouped by species and used a Tukey Honest Significant Differences test to calculate adjusted $\mathrm{P}$ values for group mean comparisons. All statistical analyses were performed in R v 4.0.2 (R Core Team 2020), and data were visualised using the ggplot2 package (Wickham, 2016).

\section{Bioacoustic data collection and analysis}

We collected an acoustic recording of a male L. palmatus on November $28,2016\left(25.9^{\circ} \mathrm{C}\right)$ in situ at a presumed breeding site. The call was recorded using a Roland R-26 portable recorder paired with a Sennheiser ME-66 microphone at an approximate distance of $2 \mathrm{~m}$ from the male. We described the calling site and behavioural context, and prepared the male as a voucher specimen for genetic and morphological analysis (USNM 591754). The recording was archived in the Macaulay Library at the Cornell Lab of Ornithology (ML 206529). We analysed advertisement calls of $L$. rufus that were recorded in Cameroon (Amiet \& Goutte, 2017). Audio spectrograms and oscillograms were made using Raven Pro 1.4 (Cornell Lab of Ornithology), and analysed with a Fast Fourier Transformation window of 512 points, a brightness of 70 points, and a contrast of 70 points following Gilbert and Bell (2018). The following parameters were measured for each call because they capture the primary axes of variation in Leptopelis advertisement calls (Amiet \& Goutte, 2017): pulses per call, pulse duration, peak frequency $(\mathrm{Hz})$, frequency range $(\mathrm{Hz})$, and total number of notes recorded. 
a)
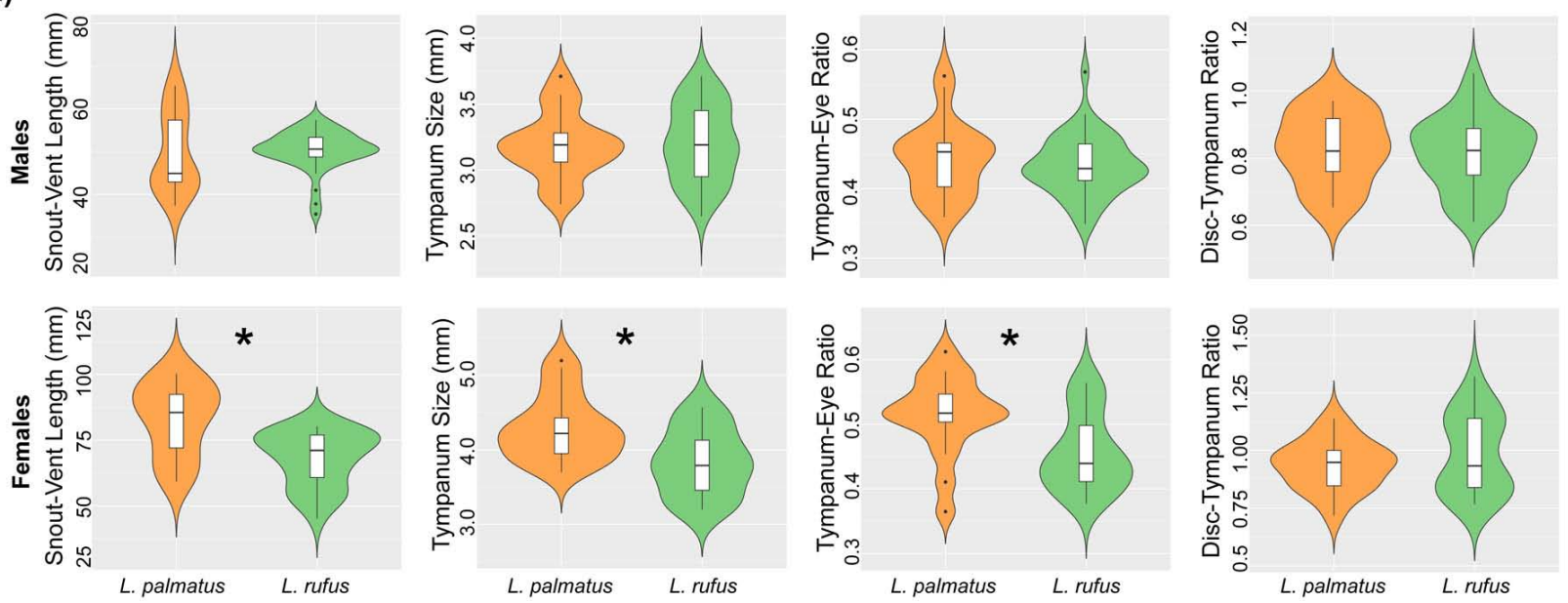

b)
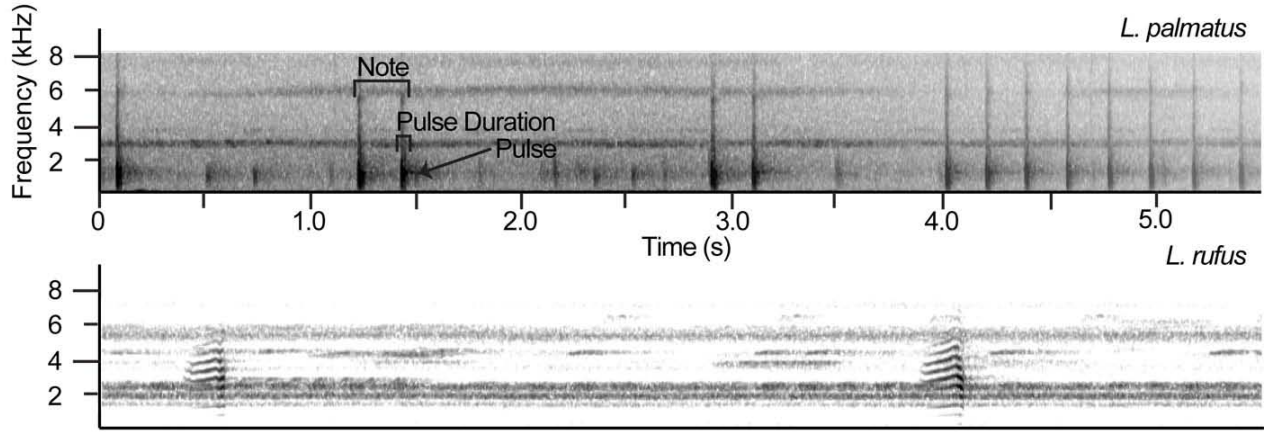

c)

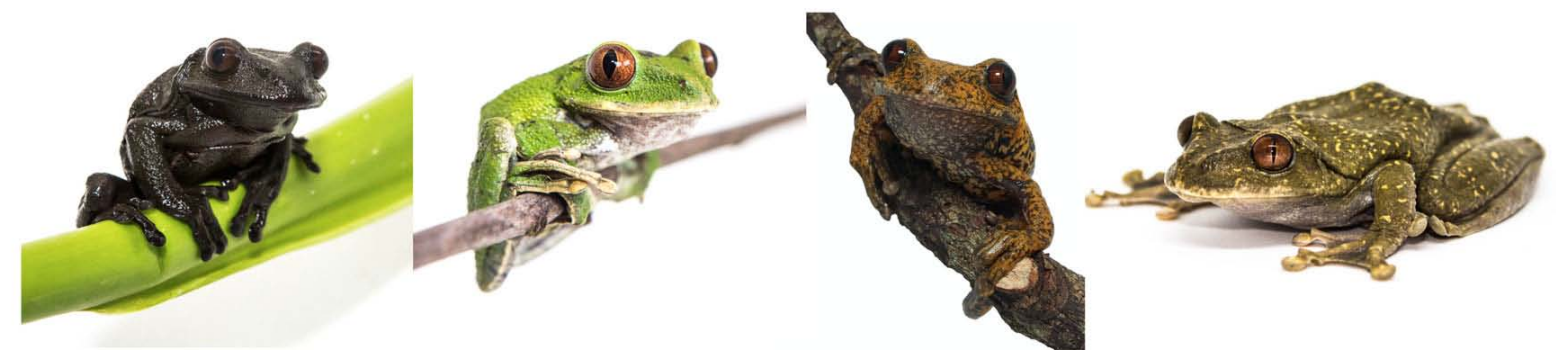

Figure 2. (a) Violin plots of adjusted Snout-Vent Length (SVL), Tympanum size (TMP), Tympanum-Eye ratio (TMP:EYE), and Disc-Tympanum ratio (DSC:TMP) in L. palmatus and L. rufus. Comparisons significant at an adjusted $\mathrm{P}<0.05$ with a Tukey Honest Significant Difference test are indicated with an asterisk. (b) Call parameter definitions and representative audio spectrograms of L. palmatus and L. rufus male advertisement calls. (c) colour variation in L. palmatus (from left to right: CAS 258958, CAS 258910, USNM 591753, USNM 591758) Photos A. Stanbridge and R. Bell.

\section{RESULTS}

Phylogenetic relationships within Leptopelis and genetic variation within L. palmatus

The 16S mtDNA gene tree of species-level relationships within the genus Leptopelis indicated strong support for the monophyly of some species groups including the largebodied West and Central African species L. rufus, L. macrotis, and $L$. millsoni, and the Ethiopian radiation $L$. vannutellii, $L$. yaldeni, L. gramineus and L. susanae (Fig. 1A). By contrast, the phylogenetic placement of most species including $L$. palmatus was poorly supported in the present dataset. However, our results indicate that $L$. palmatus does not appear to be closely related to $L$. rufus or to other, largerbodied species in the genus. We found very low diversity at $16 \mathrm{~S}$ across the range of $L$. palmatus on Príncipe Island with one dominant haplotype, three minor haplotypes, and no pattern of phylogeographic structure (Fig. 1C).

\section{Morphological divergence between $L$. rufus and $L$. palmatus}

We found that morphological differences between $L$. rufus and $L$. palmatus were distinct in females versus males. SVL, adjusted TMP size, and TMP:EYE ratios were all significantly different between female specimens of L. palmatus and L. rufus, but not male specimens (Fig. 2). Overall, L. palmatus females exhibited larger body sizes and had larger TMP than L. rufus ( $P<0.05$; Fig. $2 A)$. Likewise, the ratio of TMP:EYE was typically $>1 / 2$ in female L. palmatus and $<1 / 2$ in female $L$. rufus ( $<<0.05$; Fig. $2 A)$. DSC:TMP ratios were not significantly different between L. palmatus and L. rufus in either males or females, and none of the remaining measurements were significantly different between males of the two species (Fig. 2A). 
Table 1. Summary of call analysis for each species. Abbreviations are as follows: APF (Average Peak Frequency), APD (Average Pulse Duration)

\begin{tabular}{llccccl}
\hline Species & Location & Notes & Pulses & APF (Hz) & APD (s) & Recording Source \\
\hline L. palmatus & $\begin{array}{l}\text { Príncipe, trail from São } \\
\text { Joaquim village to Pico Príncipe }\end{array}$ & \multirow{2}{*}{14} & $1-8$ & $\begin{array}{c}1170 \\
(937-1406)\end{array}$ & $\begin{array}{c}0.04 \\
(0.03-0.05)\end{array}$ & This study (ML 206529) \\
L. rufus 1 & Cameroon, Ototomo & 6 & 1 & $\begin{array}{c}2857 \\
(2756-3359)\end{array}$ & $\begin{array}{c}0.24 \\
(0.22-0.26)\end{array}$ & Amiet \& Goute, 2017 \\
& & & & 3248 & 0.23 & Amiet \& Goute, 2017 \\
L. rufus 2 & Cameroon, Kala Afomo & 7 & 1 & $(2842-3962)$ & $(0.23-0.24)$ & \\
\hline
\end{tabular}

Calling sites, advertisement call, and colour variation in L. palmatus

We observed calling males on two occasions in 2015 (6 October 2015 and 7 October 2015) but were unable to obtain recordings. The first site was along the road between Gaspar and Sundi where we observed a calling male perched $2 \mathrm{~m}$ above ground on a vine at 1958h (CAS 258910). A gravid female was found nearby several minutes later (CAS 258911). The second site was along a small stream flowing through secondary forest in the vicinity of Nova Estrela where we found two calling males at $4 \mathrm{~m}$ (CAS 258916) and $2.5 \mathrm{~m}$ (CAS 258917) above ground at approximately 1800h. On 28 November 2016 we observed several calling males along the trail from São Joaquim village to Pico Príncipe, in a tributary of the Ribeira Banzú. Males were perched 2-3 $\mathrm{m}$ above ground on palm fronds, tree branches, and tree trunks in the vicinity of a medium stream ( $3 \mathrm{~m}$ across) and above a swampy ditch. We recorded one male (USNM 591754) at $1805 \mathrm{~h}$, which was perched approximately $2 \mathrm{~m}$ above the ground on a palm frond. The advertisement call consisted of a simple note with a dominant frequency of $1170 \mathrm{~Hz}$, average pulse duration of 0.04 seconds, and a range of pulses from 1-8 (Fig. 2B, Table 1). In the period we recorded, several calling bouts progressed from notes with one pulse to two pulses to a series of eight pulses (Fig. 2; Table 1). The waveform and structure of the $L$. palmatus call is quite different from that of $L$. rufus, which has a much higher dominant frequency $(2800+$ $\mathrm{Hz}$ ), longer average pulse duration ( 0.23 seconds), singlepulse notes, and numerous harmonics (Fig. 2B; Table 1). We documented extensive dorsal colour pattern variation in both male and female $L$. palmatus including dark green/black with or without spots, bright green, and bright yellow with dark mottling (Fig. 2C; Table S2).

\section{DISCUSSION}

Phylogenetic relationships within the genus Leptopelis are poorly understood; however, relationships among some species groups are strongly supported in our mtDNA gene tree and are consistent with phenotypically and/or geographically cohesive groups (Portillo \& Greenbaum, 2014; Reyes-Velasco et al., 2018). Although the phylogenetic placement of $L$. palmatus remains unclear, our inference does not support a close affinity to $L$. rufus, as foreshadowed by Perret's morphological comparisons (Perret, 1973). More complete taxonomic sampling and a larger genetic dataset will be necessary to establish a robust phylogenetic inference for the genus Leptopelis and to inform the biogeographic history of $L$. palmatus. Our results indicate very low genetic diversity in L. palmatus and no evidence of phylogeographic structure across its range. Two other amphibian species are also endemic to Príncipe Island: the puddle frog Phrynobatrachus dispar (Peters, 1870) and the reed frog Hyperolius drewesi Bell 2016. Both are very abundant and based on our surveys, their distributions span even more of the geographic and elevational range of the island than does L. palmatus (Loumont, 1992; Drewes \& Stoelting, 2004; Uyeda et al., 2007; Bell, 2016). Population genetic studies for both $P$. dispar and $H$. drewesi found very low genetic diversity and no patterns of genetic structure based on mtDNA-only (P. dispar, Uyeda et al., 2007) or a combination of mtDNA and genome-wide SNPs $(H$. drewesi, Bell et al., 2015). Consequently, there do not appear to be geographic barriers to gene flow across the ranges of the endemic amphibians of Príncipe.

Cryptic morphological variation has eluded species relationships in the genus Leptopelis, including nearly a century of taxonomic confusion between L. palmatus and L. rufus. Our morphological assessments of overall body size and tympanum measurements indicate significant differences between L. palmatus and L. rufus in females but not in males. In particular, the ratio of tympanum size to eye size, which has been proposed as a diagnostic character among large-bodied Leptopelis (L. macrotis, $L$. millsoni, L. palmatus, L. rufus; Schiøtz, 1999) is adequate for differentiating among L. rufus and L. palmatus females, but not males. Although the ratio of disc to tympanum width has also been proposed as diagnostic (Schiøtz, 1999), toe disc dimensions may change with preservation and be a less reliable feature to measure than tympanum or eye diameter. Sexual dimorphism in tympanum size is known in other anurans and may have functional consequences for acoustic signalling and sensitivity (Fox, 1995). Consequently, estimating acoustic sensitivity in male and female $L$. palmatus relative to male and female L. rufus would be an interesting extension of the pattern we identified here. Our results support that exceptional body size in L. palmatus is due to females reaching very large sizes whereas male body size appears to be within the range of male $L$. rufus. Despite large adult body sizes, post-metamorphic individuals of $L$. palmatus are quite small (10-11 mm; Drewes \& Stoelting, 2004) and it is unknown how long individuals take to reach 
reproductive maturity or how old very large females are. It is unclear what selective pressures (or lack thereof) on Príncipe have resulted in the apparent island gigantism of this species.

The advertisement call of $L$. palmatus is rather quiet and our observations thus far indicate that males form small breeding aggregations. The call of $L$. palmatus is quite distinct from that of $L$. rufus, further suggesting that these species are not closely related. We observed the other two island endemic anurans $P$. dispar and $H$. drewesi at breeding sites with L. palmatus. The calls of the three species are different in waveform and frequency with $P$. dispar producing long trills at higher frequencies (4500-5000 Hz; Loumont, 1992), H. drewesi producing single to multi pulsed notes at intermediate frequencies (2520-3020 Hz; Gilbert \& Bell, 2018), and $L$. palmatus producing single to multi pulsed notes at lower frequencies (937-1406 Hz; this study). Consequently, there is very little acoustic overlap between the species and passive acoustic recording devices could be an effective strategy to gather more extensive data on geographic occupancy and seasonal activity in the three species (e.g., Sugai et al., 2019).

Previous authors have reported extensive dorsal colour pattern variation in $L$. palmatus ranging from dark green/black with or without small white spots to light brown and bright green (Manaças, 1958; Loumont, 1992; Drewes \& Stoelting, 2004). We have observed all of these colour variants as well as vibrant yellow coloration with dark mottling. From our observations to date, it is not clear if colour variation differs systematically between the sexes or across ontogeny. Colour and pattern variation is known in other species of Leptopelis in which there are green phases and brown phases that may vary across ontogeny in some species (e.g., L. bocagii, L. boulengeri, L. cynnamomeus, L. mossambicus, L. natalensis, L. notatus, L. occidentalis, L. ragazzii, L. susanae, L. vermiculatus, L. uluguruensis, L. yaldeni; Schiøtz, 1999; Amiet, 2012). The genetic basis and ecological relevance of this colour pattern variation have not yet been characterised and coloration in L. palmatus seems to be among the most variable of all species in the genus.

Extensive surveys indicate the Príncipe giant tree frog, L. palmatus, is primarily found in forested habitats from sea level to over 600 m elevation (Loumont, 1992; Drewes \& Stoelting, 2004; this study). Consistent with previous survey efforts, we found both males and females perched one meter or higher off the ground on branches or leaves, especially near small, flowing streams at night (Loumont, 1992; Drewes \& Stoelting, 2004). Previous reports indicated that large females may be encountered on or near the ground (Drewes \& Stoelting, 2004); correspondingly, we encountered one large female (CAS $258958 \mathrm{SVL}=100.0 \mathrm{~mm}$ ) on the ground near a waterfall at $1245 \mathrm{~h}$, a second large female (USNM $591753 \mathrm{SVL}=$ $76.6 \mathrm{~mm}$ ) on a thin branch approximately $20 \mathrm{~cm}$ above ground in the forest at $1735 \mathrm{~h}$, a third large female (CAS $261010 \mathrm{SVL}=97.7 \mathrm{~mm}$ ) on a tree root approximately 10 $\mathrm{cm}$ above ground near a wide, muddy stream at $1817 \mathrm{~h}$, and a fourth large female (USNM 591798 SVL $=90.5$ $\mathrm{mm}$ ) in a puddle in the road at $1943 \mathrm{~h}$. Unfortunately, the reproductive biology of $L$. palmatus is entirely unknown and we have been unsuccessful in locating eggs/larvae or observing amplexus in this species whereas we have observed egg deposition sites and collected larvae of the other two anuran species on Príncipe (RCD, RCB, per. obs.). Documenting this species' reproductive mode and specific breeding habitat will be critical to understanding the habitats $L$. palmatus relies upon throughout its lifecycle.

Our study confirms the distinctiveness of $L$. palmatus relative to other large-bodied tree frogs in the genus. Our mtDNA gene tree for the genus Leptopelis indicated that continental species of large tree frogs ( $L$. rufus, $L$. macrotis, $L$. millsoni) form a distinct clade, and that $L$. palmatus is not closely related to this species group, reinforcing that gigantism has evolved multiple times in the genus. We found low mtDNA diversity and high colour variation within L. palmatus, suggesting no mtDNA genetic structure associated with phenotypic variation across the island, although more studies are needed to characterise the genetic basis and ecological relevance of colour variation. Morphological differences between $L$. palmatus and $L$. rufus are most apparent in females, which could be in part why taxonomic confusion persisted for decades. Finally, we demonstrated that the advertisement call of $L$. palmatus is markedly distinct from $L$. rufus and further supports $L$. palmatus being distinct from $L$. rufus. Future studies that describe the reproductive strategy of $L$. palmatus will provide essential information to guide conservation of this unique and endangered species.

\section{ACKNOWLEDGEMENTS}

We thank the Ministry of Environment (Director General A. de Ceita Carvalho, V. Bonfim, and S. Sousa Pontes) and J. C. Cassandra for research permits and permission to export specimens for study, Roça Belo Monte Hotel for logistical support; P. Dias, O. da Conceição Rocha, L. Esposito, M. Jerónimo, L. Scheinberg, F. Spina, and A. Stanbridge for assistance in the field; and L. Scheinberg, J. Vindum, C. Spencer, J. Sites and B. Stuart who provided access to specimens in their care. Portions of the laboratory and computer work were conducted in and with the support of the L.A.B. facilities of the National Museum of Natural History (NMNH). This work was supported by the Gulf of Guinea Fund at the California Academy of Sciences and a research grant from the Associate Director of Science at NMNH. K.E.J. was supported by the Natural History Research Experiences (NHRE) REU program (NSF grant OCE:1560088). E.A.M. was supported by the Peter Buck and Rathbone Bacon Fellowship from the National Museum of Natural History (NMNH). We thank Ivan Prates for help translating the Portuguese abstract and three anonymous reviewers whose comments improved the manuscript. 


\section{REFERENCES}

Ahl, E. (1931). Anura III, Polypedatidae. Das Tierreich 55, 1-477. Amiet, J-L. (2012). Les Rainettes du Cameroun (Amphibiens Anoures). Saint-Nazaire, France: J.-L. Amiet, Nyons, France and La Nef des Livres.

Amiet, J-L. \& Goutte, S. (2017). Chants d'amphibiens du Cameroun. Saint-Just-La-Pendue, France: J.-L. Amiet, Nyons, France.

Andersson, L.G. (1909). Uber einige der Hylambates-Foramen Kameruns. Jahrb. Nassau. Ver. Naturk 62, 103-110.

Bell, R.C., Drewes, R.C., \& Zamudio, K.R. (2015). Reed frog diversification in the Gulf of Guinea: Overseas dispersal, the progression rule, and in situ speciation. Evolution 69, 904-915.

Bell, R.C. (2016). A new species of Hyperolius (Amphibia: Hyperoliidae) from Príncipe Island, Democratic Republic of São Tomé and Príncipe. Herpetologica 72, 353-351.

Boulenger, G.A. (1882). Catalogue of the Batrachia Salientia of the British Museum, $p$ 1-503.

Boulenger, G.A. (1906). Report on the batrachians collected by the late L. Fea in West Africa. Annali del Museo Civico di Storia Naturale di Genova Serie 3 2, 157-172.

Ceríaco, L. (2016). Amphibia collection of the Museu Nacional de História Natural e da Ciência, Universidade de Lisboa, Portugal. Museu Nacional de História Natural e da Ciência. Occurrence dataset DOI: 10.15468/qe8u2w.

Ceríaco, L. \& Marques, M. (2018). São Tomé and Príncipe Herpetological Collection - IICT. Version 1.3. Instituto de Investigação Científica Tropical. Occurrence dataset DOI: 10.15468/vr54b1.

Channing, A. \& Rödel, M-O. (2019). Field guide to the frogs and other amphibians of Africa. Struik Nature, Cape Town.

Clement, M., Posada, D. \& Crandall, K.A. (2000). TCS: a computer program to estimate gene genealogies. Molecular Ecology 9(10), 1657-1659.

Darriba, D., Taboada, G.L., Doallo, R. \& Posada, D. (2012). jModelTest 2: more models, new heuristics and par- allel computing. Nature Methods 9(8), 772.

Drewes, R.C. \& Stoelting, R.E. (2004). The California Academy of Sciences Gulf of Guinea Expedition (2001) II. Additions and corrections to our knowledge of the endemic amphibians of Sao Tome and Principe. Proceedings of the California Academy of Sciences 55, 573-587.

Drummond, A.J., Suchard, M.A., Xie, D. \& Rambaut, A. (2012). Bayesian phylogenetics with BEAUti and the BEAST 1.7. Molecular Biology and Evolution 29(8), 1969-1973.

Fox, J.H. (1995) Morphological correlates of auditory sensitivity in anuran amphibians. Brain, Behavior and Evolution 45 327-338.

Gilbert, C.M., \& Bell, R.C. (2018). Evolution of advertisement calls in an island radiation of African reed frogs. Biological Journal of the Linnean Society 123, 1-11.

Idris, O.N. (2004). Taxonomy, phylogeny, and biogeography of the African treefrog species of the genus Leptopelis (Hyperoliidae). Doctoral Dissertation, The University of Texas at Arlington.

IUCN SSC Amphibian Specialist Group. 2020. Leptopelis palmatus. The IUCN Red List of Threatened Species 2020: e.T56275A149768383. DOI: 10.2305/IUCN.UK.2020-3.RLTS. T56275A149768383.en.
Katoh, K., Misawa, K., Kuma, K.I. \& Miyata, T. (2002). MAFFT: a novel method for rapid multiple sequence alignment based on fast Fourier transform. Nucleic Acids Research 30(14), 3059-3066.

Katoh, K. \& Standley, D.M. (2013). MAFFT multiple sequence alignment software version 7: improvements in performance and usability. Molecular Biology and Evolution 30(4), 772-780.

Leigh, J.W. \& Bryant, D. (2015). POPART: full-feature software for haplotype network construction. Methods in Ecology and Evolution 6(9), 1110-1116.

Loumont, C. (1992). Les amphibiens de São Tomé et Príncipe: révision systématique, cris nuptiaux et caryotypes. Alytes 10, 37-62.

Manaças, S. (1958). Anfíbios e Répteis das ilhas de São Tomé e do Príncipe e do llhéo das Rolas. Conferência Internacional dos Africanistas Ocidentais, Vol IV, Junta Investigação do Ultramar Lisboa, pp 179-192.

Mertens, R. (1965). Die Amphibien von Fernando Poo. Bonner Zoologische Beiträge 16(1965), 14-29.

Mocquard, F. (1902). Sur des Reptiles et Batraciens de l'Afrique orientale anglaise, du Gabon et de la Guinée française (région de Kouroussa). Bulletin du Muséum d'Histoire Naturelle de Paris 8, 404-417.

Nieden, F. (1910). Die Reptilien (ausser den Schlangen) und Amphibien. Fauna Deutsch Kolonien, Kamerun 2, 1-74.

Palumbi, S.R., Martin, A., Romano, S., McMillan, W.O., Stice, L. \& Grabowski, G. (1991). The Simple Fool's Guide to PCR, Version 2.0. University of Hawaii.

Parker, H.W. (1936). The Amphibians of the Mamfe Division, Cameroons. - I.Zoogeography and Systematics. Proceedings of the Zoological Society of London 106(1), 135-163.

Perret, J-L. (1962). Révision des types de Leptopelis et note sur quelques Hyperolius (Amphibia Salientia) de la région camerounaise, conservés au Museum de Berlin. Revue Zoologique Botanique Africaine 65, 235-246.

Perret, J-L. (1973). Leptopelis palmatus et Leptopelis rufus, deux espèces distinctes. Annales del al Faculté des Sciences du Yaoundé 15-16, 81-90.

Portik, D.M., Bell, R.C., Blackburn, D.C., Bauer, A.M., Barratt, C.D., Branch, W.R., Burger, M., Channing, A., Colston, T.J., Conradie et al. (2019). Sexual dichromatism drives diversification within a major radiation of African amphibians. Systematic Biology 68(6), 859-875.

Portillo, F. \& Greenbaum, E. (2014). At the edge of a species boundary: A new and relatively young species of Leptopelis (Anura:Arthroleptidae) from the Itombwe Plateau, Democratic Republic of the Congo. Herpetologica 70(1), 100-119.

Rambaut, A., Drummond, A.J., Xie, D., Baele, G. \& Suchard, M.A. (2018) Posterior summarization in Bayesian phylogenetics using Tracer 1.7. Systematic Biology 67(5), 901.

R Core Team (2020). R: A language and environment for statistical computing. R Foundation for Statistical Computing, Vienna, Austria. URL https://www.R-project.org/.

Reyes-Velasco, J., Manthey, J. D., Freilich, X. \& Boissinot, S. (2018). Diversification of African tree frogs (genus Leptopelis) in the highlands of Ethiopia. Molecular Ecology 27(9), 2256-2270.

Schiøtz, A. (1963). The amphibians of Nigeria. Videnskabelige Meddelelser fra Dansk Naturhistorisk Forening i Kjøbenhavn 125, 1-92. 
Schiøtz, A. (1999). Treefrogs of Africa. Edition Chimaira. Franfurt, Germany.

Stadler, T. (2009). On incomplete sampling under birth-death models and connections to the sampling-based coalescent. Journal of Theoretical Biology 261(1), 58-66.

Sugai, L.S.M., Silva, T.S.F., Ribeiro, J.W. \& Llusia, D. (2019). Terrestrial passive acoustic monitoring: review and perspectives. BioScience 69(1), 15-25.

Thorpe, R.S. (1975). Quantitative handling of characters useful in snake systematics with particular reference to intraspecific variation in the Ringed Snakes Natrix natrix (L.). Biological Journal of the Linnean Society 7(1), 27-43.

Thorpe, R.S. (1983a). A review of the numerical methods for recognizing and analyzing racial differentiation. Pp. 404-423 in Numerical Taxonomy: Proceedings of a NATO Advanced Studies Institute NATO ASI series, Volume G1 (J. Felsenstein, ed.). Berlin; Heidelburg, Germany: Springer Verlag.

Thorpe, R.S. (1983b). A biometric study of the effects of growth on the analysis of geographic variation: Tooth number in green geckos (Reptilia: Phelsuma). Journal of Zoology 201(1):13-26.
Turan, C. (1999). A note on the examination of morphometric differentiation among fish populations: The Truss System. Turkish Journal of Zoology 23, 259-263.

Uyeda, J.C., Drewes, R.C. \& Zimkus, B.M. (2007). The California Academy of Sciences Gulf of Guinea Expeditions (2001, 2006) VI. A new species of Phrynobatrachus from the Gulf of Guinea Islands and a reanalysis of Phrynobatrachus dispar and P. feae (Anura: Phrynobatrachidae). Proceedings of the California Academy of Sciences 58(18), 367-385.

de Witte, G.F. (1941). Exploration du Parc national Albert, Batraciens et Reptiles. Institut des Parcs Nationaux du Congo Belge 33, 1-261.

Wickham, H. (2016). ggplot2: Elegant Graphics for Data Analysis. Springer-Verlag New York. ISBN 978-3-319-24277-4

Accepted: 17 March 2021

Please note that the Supplementary Materials are available via the Herpetological Journal website: https://thebhs.org/publications/the-herpetological-journal/volume-31-number3-july-2021 